\section{Pigeons and Weather Warnings}

IN the Standard of the 5 th instant is an account of a pigeon. race from Penzance to London, a distance of 270 miles, which was done by one bird in 5 hours 34 minutes, and by another in 5 hours and 59 minutes. Might not the carrier-pigeon be employed to bring accounts of the weather 300,400 , or even 500 miles out in the Atlantic, being despatched on outward voyages by ships leaving ports such as Queenstown, Southampton, Dartmouth, Plymouth, or Falmouth? The great difficulty in our system of weather-warnings is that storms reach us unannounced over the Atlantic, because stations are of course out of the question on the ocean. If the daily sailings of steamers from various ports could be utilised by means of pigeons, this void might to some degree be filled. If it be true that many storms come to us along the course of the Gulf Stream, a branch of it (Rennell's Current) would be met a little beyond the Scilly Islands, say 100 miles farther out, or about 150 miles from Falmouth. If a bird brought a weather warning in three hours from what would appear to be an important point, it would surely advance matters a good deal. A great part of England can be warned from the Irish coast, but Scotland has no advance-guard of this sort. Steamers leaving Greenock for America could carry pigeons and send warnings back, thus giving Scotland some protection.

Putney, August 5

\section{Napoleon III, and the Nicaraguan Canal}

AT p. 249 of NATURE, vol. xx. it is made to appear as if the circumstance of the connection of the late Emperor of the French with the scheme of Central American canalisation through Nicaragua, was quite unknown to the public. But it is well known that Prince Louis N. Bonaparte, whilst at Ham, was in communication with Don Francisco Castillon, envoy to Louis Phillippe from the Nicaraguan Government upon this subject. After the escape of Louis Napoleon from France, he publicly advocated the project of the Nicaraguan Canal at the Institution of Civil Engineers, London. (Vide Proceedings I. C. E., I847, vol. vi. p. 427 ; vide "The Gate of the Pacific," by Commander Bedford Pim, pp. Ir8, et seq.) S. P. O.

\section{Vitality of the Common Snail}

AT the beginning of July last year, I placed a couple of the Helix aspersa into a closed pot of earth immediately after copulation. They soon sealed themselves up, and so remained till the middle of May of this year, when it was discovered that of one of them that had died not a vestige was left except the empty shell. The other had shrunk to about a third its former bulk, but on being moistened and supplied with food, soon began to eat and to thrive. It had to trust largely to chance for its provender, but notwithstanding this, by the end of two months it was as big as its present quarters would allow it to be. The natural thing would have been to secrete more shell, for the animal was not full grown. Instead of this, however, it burrowed in the ground, and fell to laying eggs, the greater part of which have hatched out-a little colony of vigorous young snails. Had their parent been kept supplied with food and water after impregnation, they would, of course, have begun life a year ago. I wonder how high up in the animal scale such temporary suspension of the earliest stages of development is possible?

Trinity College, Cambridge, August 7 JAMES WARD

\section{OUR ASTRONOMICAL COLUMN}

VARIABLE STARS. - It may be hoped that some amateur in the other hemisphere-the class of observation is hardly suited to the professional astronomer, considering the work that remains to be accomplished in the southern heavens-may be keeping in view Lacaille's star, $\mu$ Doradûs, which is certainly variable to a great extent, and in a very long period. In the Catalogue published by the British Association founded upon the observations in Lacaille's Celum Australe Stelliferum, the star is rated $5 \mathrm{~m}$., though in the Catalogue at the end of this work we find it $6 \mathrm{~m}$., the estimate applying to the year $175 \mathrm{r}$, and this is also the magnitude noted by Brisbane about 1825. The variability of the star was first shown by the late Capt. Jacob's observations at Madras early in I850; he found no such conspicuous star as Lacaille and Brisbane had observed, but fixed the position of one which nearly agrees with the Paramatta place, and which was estimated 9.5 ; this star was reobserved at Madras in 1855 and rated $9^{\circ} 2$. The next we hear of it is from Moesta, who, observing at Santiago, states (Astron. Nach., No. I,545) that from February, 1860, to January, I 865 , he had found it $8 \frac{1}{2}$ or 9 on Argelander's scale. Finally Mr. Stone observed the star at the Cape of Good Hope in 1875 and estimated it a seventh magnitude, which should induce a close watch upon it at the present time. The star was formerly credited with a very sensible proper motion, but it would appear from the modern observations that this arose from an error in Lacaille; thus, bringing up all places to $1875^{\circ} \circ$ we have-

\begin{tabular}{|c|c|c|c|c|c|}
\hline & & & $\begin{array}{c}\text { Right } \\
\text { Ascension. }\end{array}$ & & $\begin{array}{l}\text { North Polar } \\
\text { distance. }\end{array}$ \\
\hline Lacaille & I75I December & & $\begin{array}{cc}\text { h. m. s. } \\
56 & 2 \cdot 2\end{array}$ & $\ldots$ & I $5 \dot{1} 573$ \\
\hline Brisbane & 1825 & $\ldots$ & $555^{*} 42$ & $\ldots$ & I5 $5755^{\circ} 2$ \\
\hline Jacob & $185^{\circ}$ & $\ldots$ & $53 \cdot 16$ & $\ldots$ & $59^{\circ} 3$ \\
\hline - & 1855 & $\ldots$ & 53.34 & $\cdots$ & $57^{\circ} \mathrm{O}$ \\
\hline tone & 1875 & $\ldots$ & 52.74 & $\ldots$ & $59 \cdot 3$ \\
\hline
\end{tabular}

There appears a suspicion of a similar case with regard to the star Brisbane 5935, observed once at Paramatta and estimated $6 \mathrm{~m}$. This star does not occur in Lacaille, but it was looked for in 1850 by Jacob, who found only one $9.10 \mathrm{~m}$. near the place given by Brisbane, differing however $4 \mathrm{~s}$. in R.A. and $I^{\prime} I 8^{\prime \prime}$ in N.P.D. Mr. Stone's nearest star is Lacaille 7093. If the objects observed by Brisbane and Jacob are identical, proper motion as well as variability will enter into the case.

The observations of Julius Schmidt at Athens in 1878 again show great irregularity in the variation of $R$. Scuti, the mean period he obtained for that year being $62 \% 3$ days, instead of $7 \mathrm{I} \cdot \mathrm{r}$ days, as determined by Prof. Schönfeld, and which was satisfactory in 1869 . The last epochs determined at Athens in 1878 were, for a maximum, November 8 , and for a minimum, October $1 \mathrm{r}$. The mean period of a Herculis in the past year was found to be 97.3 days, but the period varied from 86 to II 3 days. In such instances it is obvious that observations, made as continuously as possible can alone determine whether the fuctuations follow any definite law.

The Minor Planets. - The discovery of a small planet by Prof. Peters at Clinton, N.Y., on July 28 , raises the number of known members of the group to two hundred, the object detected by the same astronomer on July 16 proving to be an old acquaintance,-No. 77 (Frigga), which had not been recognised for upwards of ten years. Of the planets discovered during the present year, No. I93 (Coggia, February 28) has been named Ambrosic, No. I96 (Peters, May I7), Philomela, and No. I98 (Borrelly, June I3), Ampella.

The. Satellites Mimas and Hyperion.-According to elements which have been previously used in this column, Mimas would be found at its greatest eastern elongation on August 20 , at $13 \mathrm{~h} .47 \mathrm{~m}$. G.M.T., distant $30^{\prime \prime}$ from Saturn's centre or $8^{\prime \prime}$ from the extremity of the ring; the period of revolution may be assumed $0^{\circ} 94243 \mathrm{~d}$. It appears difficult to make reliable prediction of the position of Hyperion from present uncertainty as to the motion of the line of apsides. Prof. Asaph Hall adopts a retrograde motion of less than $3^{\circ}$ annually, but there are indications that the true motion may be in the opposite direction, and to a much greater amount. Mr. Marth, who has devoted so much time and labour to the motions of the satellites of Saturn, was of opinion some ten years since that the revolution of the line of apsides of $F y$ perion would be found to be very rapid, through the perion would be found to be very ratite Titan. Three periods of Hyperion are almost exactly equal to four periods of Titan, if we adopt Prof. Hall's period for the former. 